\title{
Bartonella Henselae Initial Infection of Mature Human Erythrocytes Observed in Real Time Using Bacterial Endogenous Fluorescence
}

Gislaine Vieira-Damiani ${ }^{1}{ }^{\star}{ }^{\star}$, Marna Elise Ericson ${ }^{3}$, Marilene Neves da Silva ${ }^{1}$, Kalpna Gupta ${ }^{4}$, Tania Benetti Soares ${ }^{1}$, Amanda Roberta de Almeida ${ }^{1}$, Vitor Bianchin Pelegati ${ }^{5}$, Mariana Ozello Baratti ${ }^{5}$, Carlos Lenz Cesar ${ }^{5}$, Maria Letícia Cintra ${ }^{6}$ and Paulo Eduardo Neves Ferreira Velho'

${ }^{1}$ Division of Dermatology, Department of Medicine, State University of Campinas, Medical Sciences School, Campinas, Brazil

${ }^{2}$ Parana Federal Institute of Education, Science and Technology, Brazil

${ }^{3}$ Department of Dermatology, University of Minnesota Medical School, Minneapolis, USA

${ }^{4}$ Division of Hematology, Oncology and Transplantation, Department of Medicine, University of Minnesota Medical School, Minneapolis, USA

${ }^{5}$ National Institute of Science and Technology on Photonics Applied to Cell Biology (INFABIC), Brazil

${ }^{6}$ Department of Pathology, State University of Campinas, Medical Sciences School, Campinas, Brazil

\begin{abstract}
Bartonella henselae is a causative agent of anemia, cat scratch disease, bacillary angiomatosis, recurrent fever, hepatitis, endocarditis, chronic lymphadenopathy, joint and neurological disorders. B. henselae are intra-erythrocytic bacteria. The goal of this study was to visualize the $B$. henselae invasion into enucleated human red blood cells in real time using bacterium endogenous fluorescence. We took advantage of the unique fluorescence emission spectral profile of the bacteria. We used a linear unmixing approach to separate the fluorescence emission spectra of human erythrocytes from native $B$. henselae when excited at $488 \mathrm{~nm}$. Human blood samples were inoculated with $B$. henselae and incubated for 60 hours. 3-D live images were captured at select intervals using multi-photon laser scanning microscopy. Uninfected blood samples were also analyzed. This study revealed bacteria entering mature erythrocytes over a 60 hour time period.
\end{abstract}

Keywords: Bartonella henselae; Anemia; Recurrent fever; Endocarditis; Lymphadenopathy

\section{Introduction}

Bartonella spp. are Gram-negative, fastidious, and facultative intracellular bacteria [1] which can cause Peruvian bartonellosis (Carion's disease), cat scratch disease, bacillary angiomatosis, trench fever, endocarditis, bacteremia [2], hepatitis, chronic lymphadenopathy, joint and neurological disorders. Recognition of the clinical spectrum of Bartonella spp. infection in humans has greatly increased in the last 20 years $[3,4]$. The infection may be fatal even to immunocompetent patients [5].

$B$. henselae is the most frequently documented species of the genus to cause human infection [6]. It can infect erythrocytes of many mammals including cats, dogs, mice, rats, horse, dolphins, etc., causing cyclic bacteremia. B. henselae can also infect endothelial cells [7], macrophages [8], and pericytes [9].

The medical literature is conflicted about whether this species is able to infect mature as well as immature erythrocytes. The initial steps of erythrocyte invasion in human red blood cells (RBC) as a potential primary niche(s) of $B$. henselae is yet to be determined [10,11]. Clinical observations indicate that some Bartonella species infect mature RBC as see in Bartonella baciliformis infection. In Peruvian bartonellosis, in the initial phase of infection (Oroya fever), B. baciliformis can infect numerous erythrocytes [12], causing anemia shock which can often be fatal [13].

Previously, techniques used to visualize the blood/Bartonella spp. invasion process often included a fixation step, which can induce artifacts and limits the observation to a single time point. Because the infection process is dynamic, observing the invasion in real-time with live non-transfected mature erythrocytes will provide a better understanding of the initial invasion of mature erythrocytes.

Imaging endogenous fluorescence or natural autofluorescence does not require introduction of an exogenous reporter. Most bacteria possess unique endogenous fluorescent signals [14-18]. Images can be acquired in real time, making it an ideal technique to observe the initial steps of $B$. henselae interacting with the mature RBC. Because the endogenous fluorescence of RBCs and $B$. henselae are very similar we used linear unmixing of the respective spectra in spectral confocal microscopy, which makes a deconvolution using known spectra of each fluorophore. In this study, we used spectral imaging combined with linear unmixing to untangle the fluorescence spectral overlap of $B$. henselae and mature RBC excited at $488 \mathrm{~nm}$.

\section{Materials and Methods}

\section{Cultures}

B. henselae (Houston 1, American Type Culture Collection, Rockville, MD, ATCC 49882T) was grown on 5\% sheep blood agar plates and incubated at $37^{\circ} \mathrm{C}$ in $5 \% \mathrm{CO}_{2}$ enriched atmosphere. A bacterial suspension was generated using approximately $3 \times 10^{8}$ colony forming bacterium units (CFU) in human serum. Peripheral human blood from healthy subjects, two of the authors, was collected with EDTA and 900 $\mu \mathrm{L}$ was inoculated with $100 \mu \mathrm{L}$ of the bacterial suspension in serum. Similarly, $100 \mu \mathrm{l}$ of serum was added to a $900 \mu \mathrm{l}$ aliquot of blood to serve as a negative control. These samples were incubated at $37^{\circ} \mathrm{C}$ in $5 \%$

Corresponding author: Gislaine Vieira-Damiani, State University of Campinas (UNICAMP) Medical Sciences School, Rua Tessália Vieira de Camargo, 126 - Cidade Universitária“Zeferino Vaz", CEP: 13083-887 - Campinas - SP, Brasil, Tel/ Fax: (55) 19 3521 9134; E-mail: gislainevieirad@gmail.com

Received January 24, 2016; Accepted February 13, 2016; Published February 20, 2016

Citation: Vieira-Damiani G, Ericson ME, da Silva MN, Gupta K, Soares TB, et al. (2016) Bartonella Henselae Initial Infection of Mature Human Erythrocytes Observed In Real Time Using Bacterial Endogenous Fluorescence. J Trop Dis 4: 207. doi:10.4172/2329-891X.1000207

Copyright: (c) 2016 Vieira-Damiani G, et al. This is an open-access article distributed under the terms of the Creative Commons Attribution License, which permits unrestricted use, distribution, and reproduction in any medium, provided the original author and source are credited. 
Citation: Vieira-Damiani G, Ericson ME, da Silva MN, Gupta K, Soares TB, et al. (2016) Bartonella Henselae Initial Infection of Mature Human Erythrocytes Observed In Real Time Using Bacterial Endogenous Fluorescence. J Trop Dis 4: 207. doi:10.4172/2329-891X.1000207

$\mathrm{CO}_{2}$ enriched atmosphere for 60 hours. At select intervals (12, 24,36 and $60 \mathrm{hr}$ ), aliquots were removed, diluted $1: 1000$ in $\mathrm{NaCl} 0.9 \%$ and imaged using multi-photon laser scanning microscopy in sterile, 35$\mathrm{mm}$ glass bottom culture dishes $\left(\mathrm{CELLVIEW}^{\mathrm{TM}}\right)$ at $35^{\circ} \mathrm{C}$.

\section{Live cell imaging}

Endogenous fluorescence of erythrocytes and bacteria were acquired using a Zeiss multi-photon laser scanning microscopy system. The Zeiss scanning system LSM780 is on a Zeiss inverted microscope Axio Observer Z1 located at the National Institute of Science and Technology on Photonics Applied to Cell Biology (INFABIC) at UNICAMP, Brazil.

Samples were irradiated with a $488 \mathrm{~nm}$ Argon laser [Lasos, model LGN3001] using a $40 \times$ N.A. 1.3 oil immersion objective (EC Plan Neofluar) and scanned from 450 to $700 \mathrm{~nm}$. The epifluorescent image was detected by an array of 32 Avalanche Photodiodes at $512 \times 512$ pixels, using a pixel dwell time of $12.61 \mu \mathrm{s}$. Total scanning time of each optical section in the z-plane was15seconds. Each 3D z-stack was six optical sections acquired at 0.73 micron intervals. Initial observations (data not shown) in blood from these volunteers indicated that $3 \mathrm{D}$ image stacks acquired at the time intervals 24, 36 and, 60 hours, best demonstrate the dynamic interactions of the erythrocyte and the $B$. henselae.

Spectral imaging and linear unmixing of endogenous epifluorescence of the RBC and the $B$. henselae is accomplished by first acquiring the fluorescence emission spectral profile/library of each component, as well as the background, when irradiated at $488 \mathrm{~nm}$. This spectral library is used to determine the spectral contribution from each component, namely the RBC, the bacteria and the background. The spectral reference and measured curves are normalized to remove any influence from the intensity of each point. Spectral library profiles were collected for each time point (baseline, 24, 36 and 60 hours) to minimize contributions of any differences in time-dependent spectral properties that may have occurred. The background fluorescence is subtracted prior to unmixing the fluorescence signal contributions of the RBC and the bacterium. Linear unmixing calculates the relative contribution of the red blood cell and the bacterium to facilitate signal separation and accurate location of the bacteria with respect to the RBC [19].

\section{Results}

\section{Spectral characterization}

The emission spectra of $B$. henselae and RBC (Figure 1) were individually captured between $450 \mathrm{~nm}$ and $700 \mathrm{~nm}$ using $488 \mathrm{~nm}$ excitation. The fluorescence emission peak of B. henselae was $554 \mathrm{~nm}$ and the red blood cell peak at $589 \mathrm{~nm}$. This data is representative of three replicate experiments from each subject.

To better discern the bacteria from the red blood cells in these live imaging experiments we used spectral imaging combined with linear unmixing to untangle the fluorescence spectral overlap. Typically, unmixing is used with synthetic fluorescence reporters but we were able to take advantage of the relatively strong endogenous fluorescence of the erythrocytes and the bacteria. We used a different couple of spectra for each image. We unmixed all images with the same couple of spectra that we got from RBC and B. henselae in the image.

B. henselae infects mature human erythrocytes. In 24 hours infection, the bacteria were found adhered to the erythrocytes membrane, but still outside the cells (Figure 2). In 36 hours the bacteria were in the inside of the erythrocytes, near the edge (Figure 3). Only in
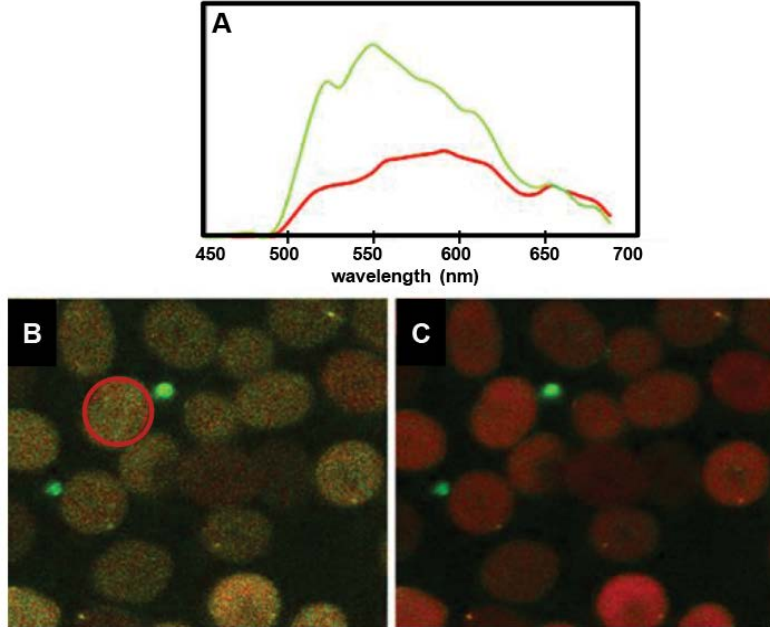

Figure 1: The emission spectra of $B$. henselae and RBC

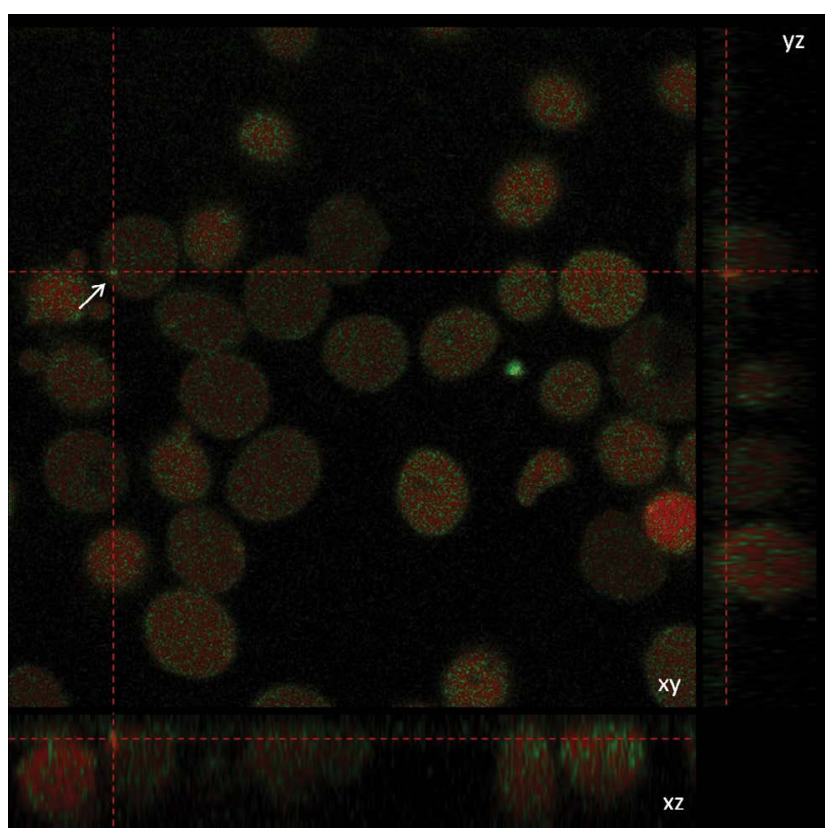

Figure 2: 24 hours after infection: $B$. henselae adhered to erythrocytes. $40 x$ N.A. 1.3 oil immersion objective.

the 60 hours images we observed B. henselae inside the red blood cells (Figure 4) which was confirmed in different axial planes (Figure 5).

\section{Discussion}

Mändle et al. [20] found the bacteria in human immature red cells in vitro, by immunofluorescence, but not in mature erythrocytes. Afterwards, in 2007, through electron microscopy [21], we demonstrated the bacteria within mature erythrocytes, and in 2012 [22], also found them within mature red cells, using fluorescence after a staining procedure with carboxyfluorescein diacetate succinimidyl ester. However, these techniques require processing of samples. In this work, we confirmed, for the first time using endogenous fluorescence, that $B$. henselae infects mature RBC. Because of the difference in 
Citation: Vieira-Damiani G, Ericson ME, da Silva MN, Gupta K, Soares TB, et al. (2016) Bartonella Henselae Initial Infection of Mature Human Erythrocytes Observed In Real Time Using Bacterial Endogenous Fluorescence. J Trop Dis 4: 207. doi:10.4172/2329-891X.1000207

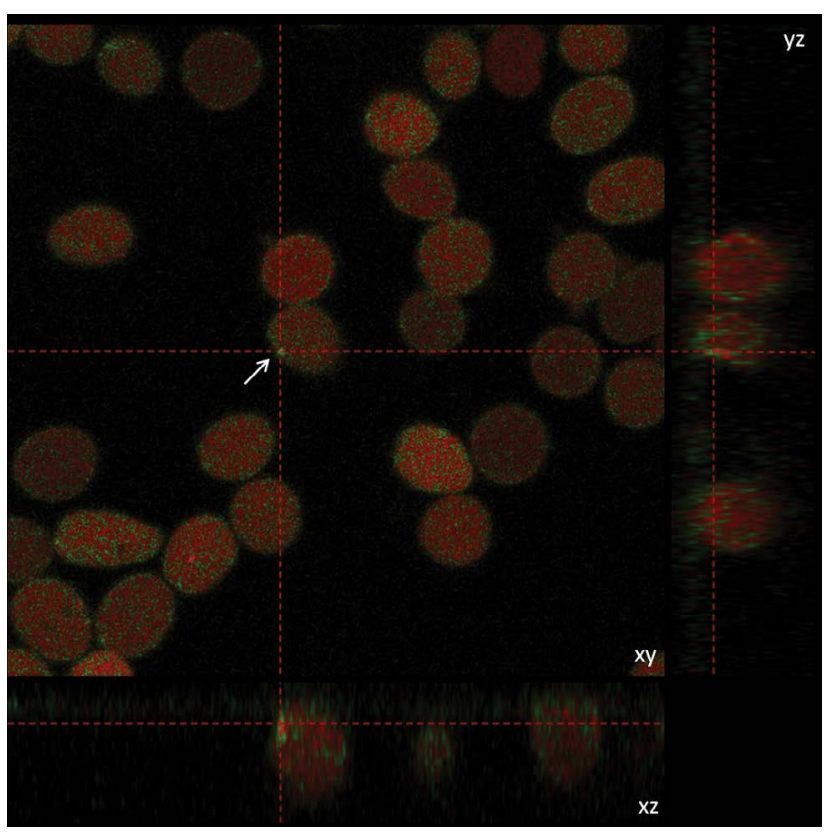

Figure 3: 36 hours after infection: Arrow: $B$. henselae entering to erythrocytes. $40 x$ N.A. 1.3 oil immersion objective.

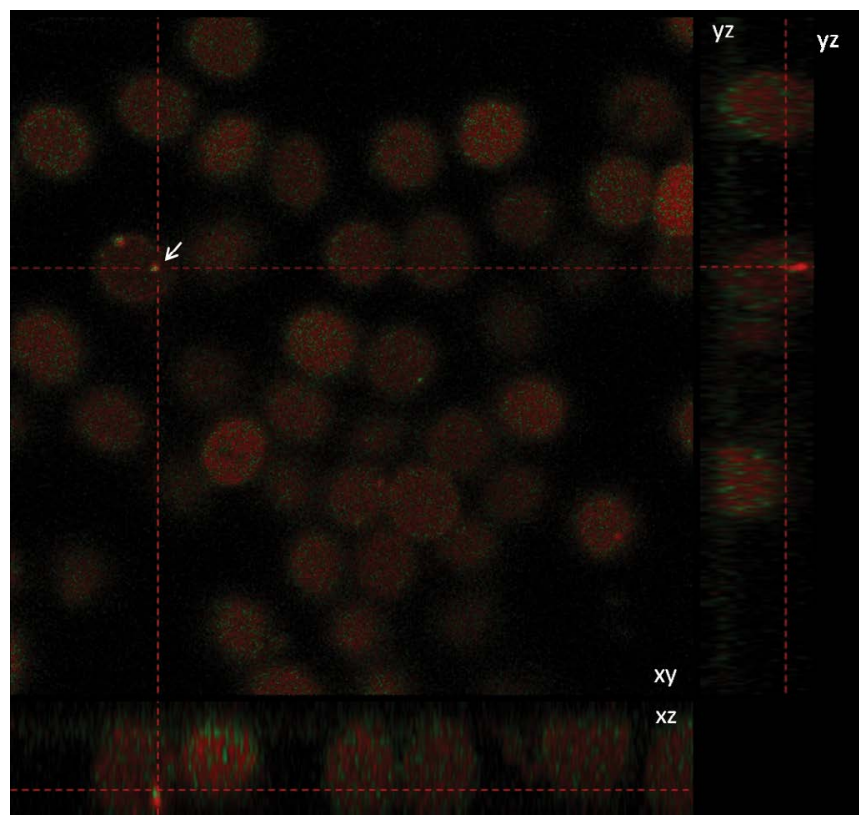

Figure 4: 60 hours after infection: Arrow: $B$. henselae inside to erythrocytes $40 x$ N.A. 1.3 oil immersion objective.

emission spectra of $B$. henselae and human RBCs we were able to visualize the time course of the bacterium invading the red cells over 60 hours. This methodology allows real-time in vivo experimentation and a new possibility to screen donated blood for Bartonella spp. as these bacteria were isolated from $1.2 \%$ (6/500) blood donors in Campinas, Brazil [23].

Real-time multiphoton microscopy enables us to track B. henselae apparent adhesion to and subsequent invasion of mature human

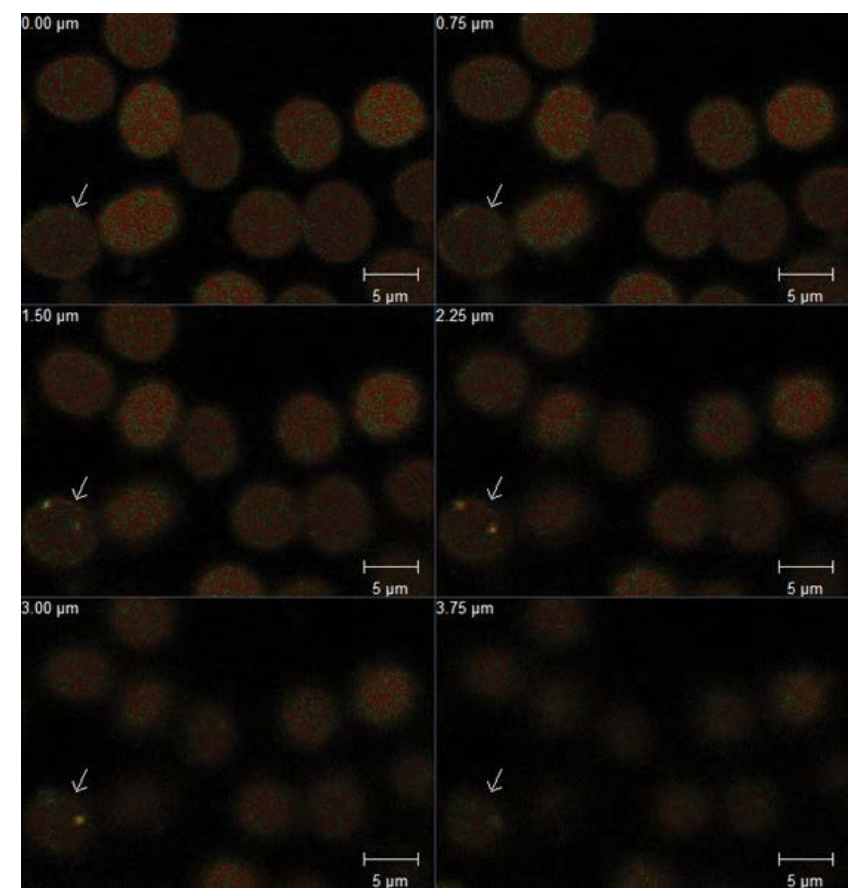

Figure 5: 60 hours after infection: Arrow: $B$. henselae inside to erythrocytes. $40 x$ N.A. 1.3 oil immersion objective.

erythrocytes. Initial observations showed that in the first twenty hours, we did not observe bacteria bind to the erythrocytes membrane or inside (data not shown). At 24 hours, 3D image analysis revealed apparent binding of the bacteria to the RBC membrane (Figure 2). At 36 hours, $B$. henselae entering to erythrocyte (Figure 3). Only at 60 hours were bacteria found inside the RBC's. Interestingly, the infected RBC harbored more than one bacterium (Figures 4 and 5).

It is possible similar mechanisms of adhesion and invasion, namely an integrin-dependent invasion [20], could play a role in the $B$. henselae invasion of RBC's, we were able to observe invasion of mature erythrocytes by $B$. henselae using real-time imaging over 60 hours with multi-photon laser scanning microscopy.

Our results corroborate with the clinical findings of anemia related to $B$. henselae infection as reported in medical literature [24-26]. $B$. henselae should be investigated in cases of anemia of unknown origin [25].

In conclusion, we observed $B$. henselae and $\mathrm{RBC}$ endogenous fluorescence spectra using a laser scanning system. By acquiring a spectral image we recognized the $B$. henselae attached to the RBC via fluorescence unmixing. We were able to detect for the first time $B$. henselae invasion in RBC in real-time using bacterium endogenous fluorescence.

\section{References}

1. Breitschwerdt EB, Maggi RG, Chomel BB, Lappin MR (2010) Bartonellosis: an emerging infectious disease of zoonotic importance to animals and human beings. J Vet Emerg Crit Care (San Antonio) 20: 8-30.

2. Maggi RG, Ericson M, Mascarelli PE, Bradley JM, Breitschwerdt EB (2013) Bartonella henselae bacteremia in a mother and son potentially associated with tick exposure. Parasit Vectors 6: 101.

3. Velho PE, Cintra ML, Uthida-Tanaka AM, de Moraes AM, Mariotto A (2003) 
Citation: Vieira-Damiani G, Ericson ME, da Silva MN, Gupta K, Soares TB, et al. (2016) Bartonella Henselae Initial Infection of Mature Human Erythrocytes Observed In Real Time Using Bacterial Endogenous Fluorescence. J Trop Dis 4: 207. doi:10.4172/2329-891X.1000207

What do we (not) know about the human bartonelloses? Braz J Infect Dis 7: $1-6$.

4. Rolain JM, Brouqui P, Koehler JE, Maguina C, Dolan MJ, et al. (2004) Recommendations for treatment of human infections caused by Bartonella species. Antimicrob Agents Chemother 48: 1921-1933.

5. Cockerell CJ, Whitlow MA, Webster GF, Friedman-Kien AE (1987) Epithelioid angiomatosis: a distinct vascular disorder in patients with the acquired immunodeficiency syndrome or AIDS-related complex. Lancet 2: 654-656.

6. Fouch B, Coventry S (2007) A case of fatal disseminated Bartonella henselae infection (cat-scratch disease) with encephalitis. Arch Pathol Lab Med 131: 1591-1594.

7. Batterman HJ, Peek JA, Loutit JS, Falkow S, Tompkins LS (1995) Bartonella henselae and Bartonella quintana adherence to and entry into cultured human epithelial cells. Infect Immun 63: 4553-4556.

8. Resto-Ruiz S, Schmiederer M, Sweger D, Newton C, Klein TW, et al. (2002) Induction of a potential paracrine angiogenic loop between human THP-1 macrophages and human microvascular endothelial cells during Bartonella henselae infection. Infect Immun 70: 4564-4570.

9. Varanat M, Maggi RG, Linder KE, Breitschwerdt EB (2013) Infection of human brain vascular pericytes (HBVPs) by Bartonella henselae. Med Microbiol Immunol 202: 143-151.

10. Mehock JR, Greene CE, Gherardini FC, Hahn TW, Krause DC (1998) Bartonella henselae invasion of feline erythrocytes in vitro. Infect Immun 66: 3462-3466.

11. Dehio C, Meyer M, Berger J, Schwarz H, Lanz C (1997) Interaction of Bartonella henselae with endothelial cells results in bacterial aggregation on the cell surface and the subsequent engulfment and internalisation of the bacterial aggregate by a unique structure, the invasome. J Cell Sci 110: 2141-2154.

12. Benson LA, Kar S, McLaughlin G, Ihler GM (1986) Entry of Bartonella bacilliformis into erythrocytes. Infect Immun 54: 347-353.

13. Gray GC, Johnson AA, Thornton SA, Smith WA, Knobloch J, et al. (1990) An epidemic of Oroya fever in the Peruvian Andes. Am J Trop Med Hyg 42: 215221.

14. Dalterio RA, Nelson WH, Britt D, Sperry J F, Tanguay JF, et al. (1987) The steady-state and decay characteristics of primary fluorescence from live bacteria. Applied Spectroscopy 41: 234-241.
15. Coburn JT, Lytle FE, Huber DM (1985) Identification of bacterial pathogens by laser excited fluorescence. Anal Chem 57: 1669-1673.

16. Saxena IF, Files DJ, Rao SV, Costerton WJ (2002) Autofluorescence-based bacteria detection using an optical fiber. Proc. SPIE 4622. Optical Diagnostics of Living Cells 4622

17. Spector BC, Reinisch L, Smith D, Werkhaven JA (2000) Noninvasive fluorescent identification of bacteria causing acute otitis media in a chinchilla model. Laryngoscope 110: 1119-1123.

18. Sorrell MJ, Tribble J, Reinisch L, Werkhaven JA, Ossoff RH (1994) Bacteria identification of otitis media with fluorescence spectroscopy. Lasers Surg Med 14: 155-163.

19. Zimmermann T, Rietdorf J, Pepperkok R (2003) Spectral imaging and its applications in live cell microscopy. FEBS Lett 546: 87-92.

20. Mändle T, Einsele $H$, Schaller M, Neumann D, Vogel W, et al. (2005) Infection of human CD34+ progenitor cells with Bartonella henselae results in intraerythrocytic presence of B. henselae. Blood 106: 1215-1222.

21. Pitassi LH, Magalhães RF, Barjas-Castro ML, de Paula EV, Ferreira MR, et al. (2007) Bartonella henselae infects human erythrocytes. Ultrastruct Pathol 31: 369-372.

22. Yuan C, Zhu C, Bai Y, Yang X, Hua V (2012) Staining of Bartonella henselae with carboxyfluorescein diacetate succinimidyl ester fortracking infection in erythrocytes and epithelial cells. Journal of Microbiological Methods Bartonella henselae 89: 102-106.

23. Pitassi LH, de Paiva Diniz PP, Scorpio DG, Drummond MR, Lania BG, et al. (2015) Bartonella spp. bacteremia in blood donors from Campinas, Brazil. PLoS Negl Trop Dis 9: e0003467.

24. Mohle-Boetani JC, Koehler JE, Berger TG, LeBoit PE, Kemper CA, et al. (1996) Bacillary angiomatosis and bacillary peliosis in patients infected with human immunodeficiency virus: clinical characteristics in a case-control study. Clin Infect Dis 22: 794-800.

25. Van Audenhove A, Verhoef G, Peetermans WE, Boogaerts M, Vandenberghe $P$ (2001) Autoimmune haemolytic anaemia triggered by Bartonella henselae infection: a case report. Br J Haematol 115: 924-925.

26. Velho PE, Pimentel V, Del Negro GM, Okay TS, Diniz PP, et al. (2007) Severe anemia, panserositis, and cryptogenic hepatitis in an HIV patient infected with Bartonella henselae. Ultrastruct Pathol 31: 373-377. 